\title{
Molecular Detection and Genotyping of Coxiella-Like Endosymbionts in Ticks Collected from Animals and Vegetation in Zambia
}

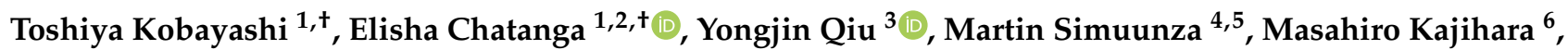 \\ Bernard Mudenda Hang'ombe ${ }^{5,7}$, Yoshiki Eto ${ }^{6}$, Ngonda Saasa ${ }^{4}$, Akina Mori-Kajihara ${ }^{6}$, Edgar Simulundu 4,8 ${ }^{1 D}$, \\ Ayato Takada ${ }^{4,6}{ }^{(D)}$, Hirofumi Sawa ${ }^{4,9}$, Ken Katakura ${ }^{1}$, Nariaki Nonaka ${ }^{1}$ and Ryo Nakao ${ }^{1, *(D)}$
}

Citation: Kobayashi, T.; Chatanga, E. Qiu, Y.; Simuunza, M.; Kajihara, M.; Hang'ombe, B.M.; Eto, Y.; Saasa, N.; Mori-Kajihara, A.; Simulundu, E.; et al. Molecular Detection and Genotyping of Coxiella-Like Endosymbionts in Ticks Collected from Animals and Vegetation in Zambia. Pathogens 2021, 10, 779. https://doi.org/10.3390/ pathogens10060779

Academic Editor: John Stenos

Received: 31 May 2021

Accepted: 19 June 2021

Published: 21 June 2021

Publisher's Note: MDPI stays neutral with regard to jurisdictional claims in published maps and institutional affiliations.

Copyright: (c) 2021 by the authors. Licensee MDPI, Basel, Switzerland. This article is an open access article distributed under the terms and conditions of the Creative Commons Attribution (CC BY) license (https:/ / creativecommons.org/licenses/by/ $4.0 /)$.
1 Laboratory of Parasitology, Department of Disease Control, Graduate School of Infectious Diseases, Faculty of Veterinary Medicine, Hokkaido University, N 18 W 9, Kita-ku, Sapporo 060-0818, Japan; kobayashi.toshiya.1009@gmail.com (T.K.); chatanga@vetmed.hokudai.ac.jp (E.C.); kenkata@vetmed.hokudai.ac.jp (K.K.); nnonaka@vetmed.hokudai.ac.jp (N.N.)

2 Department of Veterinary Pathobiology, Faculty of Veterinary Medicine, Lilongwe University of Agriculture and Natural Resources, Lilongwe P.O. Box 219, Malawi

3 Division of International Research Promotion, International Institute for Zoonosis Control, Hokkaido University, N 20 W10, Kita-ku, Sapporo 001-0020, Japan; yongjin_qiu@czc.hokudai.ac.jp

4 Department of Diseases Control, School of Veterinary Medicine, The University of Zambia, Lusaka P.O. Box 32379, Zambia; martin.simuunza@unza.zm (M.S.); nsaasa@gmail.com (N.S.); esikabala@yahoo.com (E.S.); atakada@czc.hokudai.ac.jp (A.T.); h-sawa@czc.hokudai.ac.jp (H.S.)

5 Africa Centre of Excellence for Infectious Diseases of Humans and Animals, The University of Zambia, Lusaka P.O. Box 32379, Zambia; mudenda68@yahoo.com

6 Division of Global Epidemiology, International Institute for Zoonosis Control, Hokkaido University, N 20 W10, Kita-ku, Sapporo 001-0020, Japan; kajihara@czc.hokudai.ac.jp (M.K.); y.eto@frontier.hokudai.ac.jp (Y.E.); akinam@czc.hokudai.ac.jp (A.M.-K.)

7 Department of ParaClinical Studies, School of Veterinary Medicine, The University of Zambia, Lusaka P.O. Box 32379, Zambia

8 Macha Research Trust, Choma P.O. Box 630166, Zambia

9 Division of Molecular Pathobiology, International Institute for Zoonosis Control, Hokkaido University, N 20 W10, Kita-ku, Sapporo 001-0020, Japan

* Correspondence: ryo.nakao@vetmed.hokudai.ac.jp; Tel.: +81-11-706-5196

+ These authors contributed equally to this work.

Abstract: Ticks are obligate ectoparasites as they require to feed on their host blood during some or all stages of their life cycle. In addition to the pathogens that ticks harbor and transmit to vertebrate hosts, they also harbor other seemingly nonpathogenic microorganisms including nutritional mutualistic symbionts. Tick nutritional mutualistic symbionts play important roles in the physiology of the host ticks as they are involved in tick reproduction and growth through the supply of B vitamins as well as in pathogen maintenance and propagation. Coxiella-like endosymbionts (CLEs) are the most widespread endosymbionts exclusively reported in ticks. Although CLEs have been investigated in ticks in other parts of the world, there is no report of their investigation in ticks in Zambia. To investigate the occurrence of CLEs, their maintenance, and association with host ticks in Zambia, 175 ticks belonging to six genera, namely Amblyomma, Argas, Haemaphysalis, Hyalomma, Ornithodoros, and Rhipicephalus, were screened for CLEs, followed by characterization of CLEs by multi-locus sequence typing of the five Coxiella housekeeping genes (dnaK, groEL, rpoB, 16S rRNA, and 23S rRNA). The results showed that $45.7 \%(n=80)$ were positive for CLEs. The comparison of the tick $16 \mathrm{~S}$ rDNA phylogenetic tree with that of the CLEs concatenated sequences showed that there was a strong correlation between the topology of the trees. The results suggest that most of the CLEs have evolved within tick species, supporting the vertical transmission phenomenon. However, the negative results for CLE in some ticks warrants further investigations of other endosymbionts that the ticks in Zambia may also harbor.

Keywords: Coxiella-like endosymbionts; ticks; Zambia 


\section{Introduction}

Ticks are obligate ectoparasites as they require to feed on host blood during some or all stages of their life cycle [1]. Ticks harbor and transmit a variety of pathogens to their vertebrate hosts, including protozoa such as Babesia and Theileria, bacteria such as Anaplasma, Borrelia, Ehrlichia, and Rickettsia, and viruses such as Crimean-Congo haemorrhagic fever virus [2-4]. Tick-borne pathogens (TBPs) are one of the emerging public health concerns worldwide as they pose a threat to both humans and animals $[5,6]$. Thus, the need to investigate the microorganisms that ticks harbor is important in order to understand their epidemiology, transmission dynamics, and maintenance in the host ticks, which are prerequisites to conceiving effective tick control strategies.

In addition to pathogenic organisms that ticks harbor and transmit to both animals and humans, they also harbor a wide range of seemingly nonpathogenic microbes including symbionts [7-9]. Tick symbionts have attracted much attention among the scientists in the tick research community over the last decade and are now being investigated more than before due to their importance in the physiology of the ticks. Symbiotic bacteria are involved in tick reproduction and growth through the supply of vitamins such as biotin and folate $[7,10,11]$ and are also increasingly known to be involved in pathogen maintenance and propagation in various vector arthropods $[12,13]$. Tick nutritional mutualistic endosymbionts are passed on to their offspring through vertical transmission [14,15]. Currently, three genera namely: Coxiella-like endosymbionts (CLEs), Francisella-like endosymbionts (FLEs), and Midichloria $[8,9,16,17]$ have been reported exclusively in ticks. Initially, Coxiella burnetii, the causative agent of $\mathrm{Q}$ fever, was the only species under the genus Coxiella, but a nutritional mutualistic bacterium genetically related to C. burnetii was found among tick endosymbionts [18] and was termed CLE. The presence of CLEs has been reported from tick salivary glands, ovaries, and eggs [7,19-21]. Several studies have also reported the detection and genetic characterization of CLEs from a wide range of tick species [18-20,22-26].

In Zambia, a country located in southern Africa, 16 species of ticks belonging to two families (Argasidae and Ixodidae) and five genera (Ornithodoros, Amblyomma, Haemaphysalis, Hyalomma and Rhipicephalus) were initially reported, comprising of one species of Ornithodoros, three species of Amblyomma, one species of Haemaphysalis, two species of Hyalomma, and nine species of Rhipicephalus [27]. In recent years, other tick species have also been reported in Zambia, which include one species of Argas, one species of Haemaphysalis, one species of Hyalomma, one species of Ornithodoros, and eight species of Rhipicephalus [28], bringing the total to 28 species belonging to two families and six genera. Tick-borne diseases (TBDs) such as bovine theileriosis (or East Coast Fever) caused by Theileria parva infection, bovine babesiosis (or red water) caused by Babesia bovis infection, bovine anaplasmosis (or gall sickness) caused by Anaplasma marginale infection, and heartwater caused by Ehrlichia ruminantium infection are some of the obstacles to livestock development in Zambia [29-32]. Zoonotic TBPs such as Anaplasma platys, Borrelia-like organism, the causative agent of human borreliosis, and Rickettsia africae have also been reported in Zambia [33-36].

There has been no attempt to detect and genetically characterize CLEs in ticks in Zambia. Thus, the lack of genetic information of CLEs in ticks in Zambia warrants new research in this area. Elucidating the microbiological properties of CLEs and their role in ticks will lead to a better understanding of tick physiology and survival strategies in nature, leading to the establishment of novel tick control methods. This study aimed to investigate the presence of CLEs in ticks in Zambia and to understand the mode of transmission, maintenance, and the association of CLEs with their host ticks by genotyping.

\section{Results}

\subsection{Morphological Tick Identification}

A total of 175 ticks belonging to two families (Argasidae and Ixodidae) and six genera (Amblyomma, Argas, Haemaphysalis, Hyalomma, Ornithodoros, and Rhipicephalus) were identi- 
fied morphologically under a steromicroscope using established keys [27]. At the species level, the following were identified (Amblyomma pomposum, Amblyomma variegatum, Argas walkerae, Haemaphysalis aciculifer, Haemaphysalis elliptica, Hyalomma marginatum, Hyalomma marginatum rufipes, Hyalomma truncatum, Ornithodoros faini, Rhipicephalus appendiculatus, Rhipicephalus camicasi, Rhipicephalus decoloratus, Rhipicephalus evertsi evertsi, Rhipicephalus geigyi, Rhipicephalus lunulatus, Rhipicephalus microplus, Rhipicephalus muhsamae, Rhipicephalus sanguineus, Rhipicephalus simus, Rhipicephalus sulcatus, Rhipicephalus turanicus, and unclassified Rhipicephalus spp.) for a total of 22 known and other unclassified Rhipicephalus spp.

\subsection{Molecular Identification and Phylogenetic Analysis of Ticks Based on the Mitochondrial $16 S$ rRNA Gene Sequences}

Molecular tick species identification was conducted by amplifying the partial sequences of the mitochondrial $16 \mathrm{~S}$ ribosomal RNA gene (rDNA) from at least one sample from each tick species. The results were in good agreement with the morphological identification although sequences from the same tick species were not always identical. Generally, our sequences clustered together with those sequences of the same tick species in the GenBank. Amblyomma pomposum, Am. variegutum, Hae. aciculifer, and Hae. elliptica, belonged to the same clade. Most Rhipicephalus species clustered according to their species except the members of the R. sanguineus sensu lato (s.1.); R. camicasi, R. guilhoni, R. sanguineus, R. sulcatus, and R. turanicus [37,38], which clustered into a single clade (Figure 1).

\subsection{Screening of CLE}

The nested polymerase chain reaction (PCR) assays targeting the heat shock protein gene ( $g r o E L$ ) of CLEs showed that 80/175 (45.7\%) ticks belonging to 20 species from five genera were positive (Table 1). Amblyomma pomposum, Hae. aciculifer, R. camicasi, R. evertsi evertsi, R. guilhoni, R. muhsamae, and R. simus had 100\% detection rates of CLEs. For Am. variegatum, Hae. elliptica, Hy. truncatum, O. faini, R. appendiculatus, R. decoloratus, R. geigyi, R. lunulatus, R. microplus, R. sanguineus, R. sulcatus, R. turanicus, and Rhipicephalus spp. had varying infection rates between $9 \%$ and $67 \%$. However, Ar. walkerae, Hy. marginatum rufipes, and Hy. marginatum were all negative for CLEs.

\subsection{Multi-Locus Sequence Typing of groEL, dnaK, rpoB, $16 S$ rRNA, and 23S rRNA Genes of CLE}

Based on the results of the screening for CLEs, we conducted multi-locus sequence typing (MLST) on CLE-positive samples by targeting four additional housekeeping genes: chaperone protein DnaK ( $(n a K)$, RNA polymerase beta-subunit (rpoB), $16 \mathrm{~S}$ rRNA, and 23S rRNA. When comparing the PCR success rates among four target genes, we observed that $23 S$ rRNA and $r p o B$ had higher success rates $98 \%(n=78)$ and $93 \%(n=74)$, respectively. In contrast, dnaK and 16S rRNA could only amplify 49 and 42 samples, representing success rates of $61 \%$ and $53 \%$, respectively. The percentages of variable sites for the five genes were $38.9 \%, 37.6 \%, 50.8 \%, 13.2 \%$, and $25.1 \%$ for $d n a K$, groEL, rpoB, $16 \mathrm{~S}$ rRNA, and $23 \mathrm{~S}$ rRNA, respectively.

We obtained 22 unique sequences of the groEL gene from 80 ticks belonging to 20 species from five genera; we also obtained 22 unique sequences of the $d n a K$ gene from 49 ticks belonging to 15 species from three genera. In the $r p o B$ gene 23 unique sequences were obtained from 74 ticks belonging to 19 species from four genera, while in the $16 S$ rRNA gene we obtained 27 unique sequences from 42 ticks belonging to 15 species from three genera, and 26 unique sequences of the $23 \mathrm{~S}$ rRNA gene from 78 ticks belonging to 18 species from three genera.

The 22 unique sequences of the groEL gene were designated as alleles G1 to G22. The 22 unique sequences of the $d n a K$ gene were designated as alleles D1 to D22. The 23 unique sequences of the rpoB gene were designated as alleles R1 to R23. The 27 unique sequences of the 16S rRNA gene were designated as alleles 16S-1 to 16S-27, and the 26 unique sequences of the $23 \mathrm{~S}$ rRNA gene were designated as alleles 23S-1 to 23S-26 (Table 2). The assignment of the alleles was based on the number of sequences obtained per allele i.e., the highest number of identical alleles were assigned allele 1 and the numbering continued 
in descending order of number of sequences. Where single sequences were obtained, the alleles were assigned in alphabetical order of the tick species.

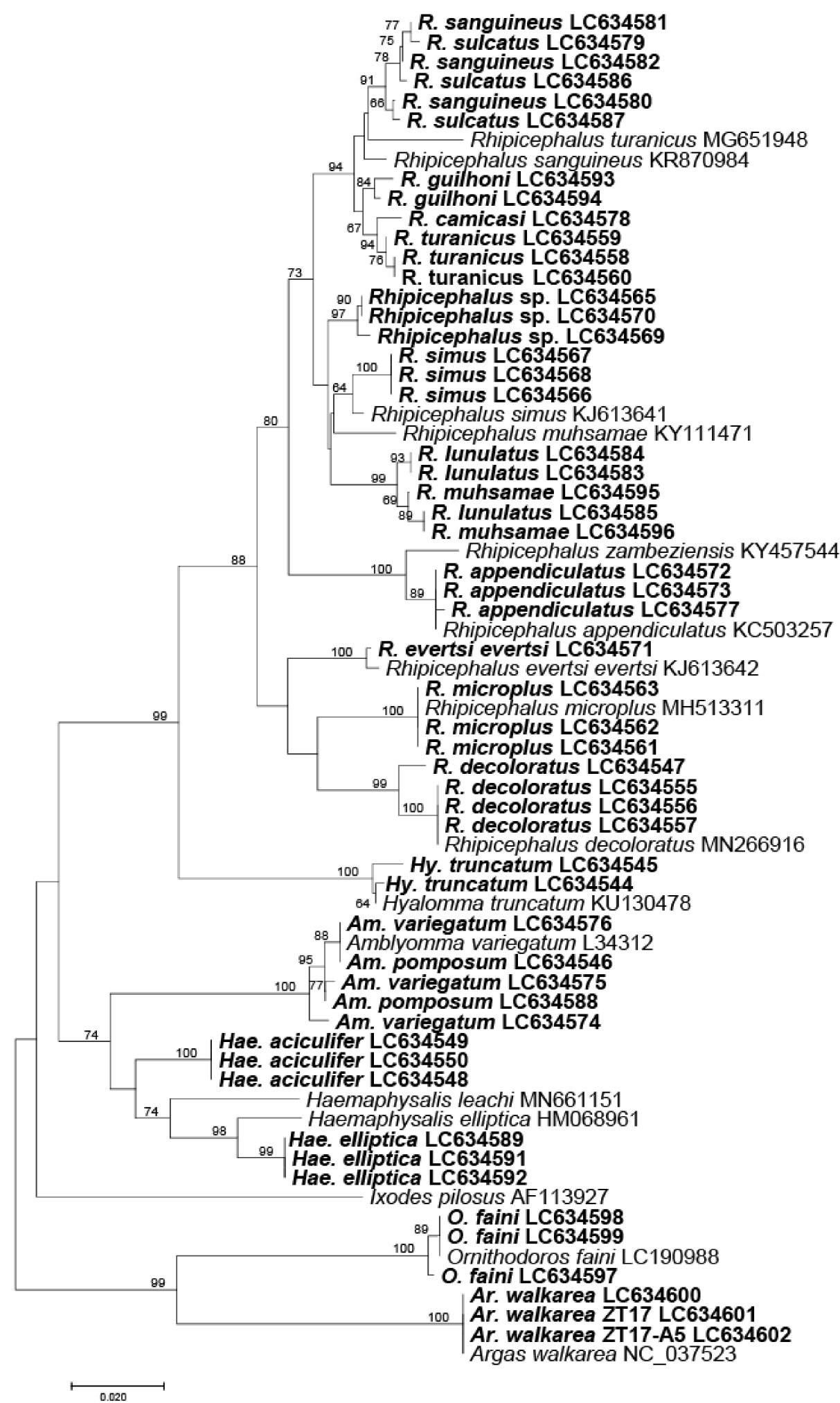

Figure 1. The phylogenetic tree based on the tick mitochondrial 16S rRNA gene partial sequences. The tree was constructed using MEGA7 based on the maximum likelihood method, using the Kimura 2-parameter model. All bootstrap values $>60$ from 1000 replications are shown on the interior branch nodes. The sequences obtained in this study are in bold. GenBank accession number is provided next to the tick species name. 
Table 1. List of tick species, details on their origin, host species or habitat, number tested, the prevalence of CLEs, and year of collection.

\begin{tabular}{|c|c|c|c|c|c|c|}
\hline Tick Species & Sampling Site & Host or Habitat & $\begin{array}{c}\text { Number Tested } \\
\text { (M; F) }\end{array}$ & $\begin{array}{c}\text { Number Positive } \\
\text { (M; F) }\end{array}$ & Positive Rate (\%) & Year \\
\hline Amblyomma pomposum & $\begin{array}{l}\text { Mpulungu, } \\
\text { Shangombo }\end{array}$ & dog, cattle & $2(1 ; 1)$ & $2(1 ; 1)$ & 100 & 2016,2017 \\
\hline Amblyomma variegatum & $\begin{array}{l}\text { Mpulungu, } \\
\text { Shangombo }\end{array}$ & cattle & $13(7 ; 6)$ & $7(3 ; 4)$ & 54 & 2016,2017 \\
\hline Argas walkarae & Isoka & vegetation & 10 (NA) & 0 & 0 & 2017 \\
\hline Haemaphysalis aciculifer & Kasanka & unknown & $9(5 ; 4)$ & $9(5 ; 4)$ & 100 & 2017 \\
\hline Haemaphysalis elliptica & $\begin{array}{l}\text { Mpulungu, } \\
\text { Shibuyunji }\end{array}$ & vegetation, unknown & $10(6 ; 4)$ & $4(2 ; 2)$ & 40 & 2017 \\
\hline Hyalomma marginatum & $\begin{array}{c}\text { Mongu, } \\
\text { Shangombo }\end{array}$ & cattle & $6(1 ; 5)$ & 0 & 0 & 2017 \\
\hline Hyalomma marginatum rufipes & Shibuyunji & unknown & $1(1 ; 0)$ & 0 & 0 & 2017 \\
\hline Hyalomma truncatum & $\begin{array}{l}\text { Shangombo, } \\
\text { Shibuyunji }\end{array}$ & cattle, vegetation & $11(4 ; 7)$ & $1(0 ; 1)$ & 9 & 2016, 2017 \\
\hline Rhipicephalus appendiculatus & $\begin{array}{l}\text { Mpulungu, } \\
\text { Shangombo }\end{array}$ & cattle, vegetation & $10(6 ; 4)$ & $4(2 ; 2)$ & 40 & 2016,2017 \\
\hline Rhipicephalus camicasi & Mpongwe & goat & $1(0 ; 1)$ & $1(0 ; 1)$ & 100 & 2017 \\
\hline Rhipicephalus decoloratus & Mpongwe & cattle & $10(5 ; 5)$ & $4(2 ; 2)$ & 40 & 2017 \\
\hline Rhipicephalus evertsi evertsi & Mpongwe & cattle & $1(0 ; 1)$ & $1(0 ; 1)$ & 100 & 2017 \\
\hline Rhipicephalus geigyi & Mongu & cattle & $5(0 ; 5)$ & $1(0 ; 1)$ & 20 & 2017 \\
\hline Rhipicephalus guilhoni & Mpulungu & vegetation & $2(2 ; 0)$ & $2(2 ; 0)$ & 100 & 2017 \\
\hline Rhipicephalus lunulatus & $\begin{array}{c}\text { Isoka, } \\
\text { Shangombo }\end{array}$ & dog, goat & $12(5 ; 7)$ & $6(2 ; 4)$ & 50 & 2016,2017 \\
\hline Rhipicephalus microplus & Mpongwe & cattle & $9(3 ; 6)$ & $3(1 ; 2)$ & 33 & 2017 \\
\hline Rhipicephalus muhsamae & Mpulungu & vegetation & $2(2 ; 0)$ & $2(2 ; 0)$ & 100 & 2017 \\
\hline Rhipicephalus sanguineus & $\begin{array}{l}\text { Mpulungu, } \\
\text { Shangombo }\end{array}$ & $\operatorname{dog}$ & $13(6 ; 7)$ & $7(2 ; 5)$ & 54 & 2016, 2017 \\
\hline Rhipicephalus simus & Mwinilunga & unknown & $8(5 ; 3)$ & $8(5 ; 3)$ & 100 & 2017 \\
\hline Rhipicephalus sulcatus & Mpulungu & cattle & $6(4 ; 2)$ & $4(2 ; 2)$ & 67 & 2017 \\
\hline Rhipicephalus turanicus & Mpongwe & vegetation & $10(7 ; 3)$ & $4(2 ; 2)$ & 40 & 2017 \\
\hline Rhipicephalus spp. & Isoka & cattle & $14(8 ; 6)$ & $8(3 ; 5)$ & 57 & 2017 \\
\hline Totals & & & $175(82 ; 83)$ & $80(38 ; 42)$ & 45.7 & \\
\hline
\end{tabular}

M, male; F, female; NA, not available.

Table 2. Multi-locus sequence typing of five CLE genes.

\begin{tabular}{|c|c|c|c|c|c|c|c|c|c|c|c|c|c|c|c|}
\hline \multirow{3}{*}{ Tick Species } & \multicolumn{15}{|c|}{ CLE Target Gene } \\
\hline & \multicolumn{3}{|c|}{ groEL } & \multicolumn{3}{|c|}{$d n a K$} & \multicolumn{3}{|c|}{ гров } & \multicolumn{3}{|c|}{ 16S rRNA } & \multicolumn{3}{|c|}{$23 S$ rRNA } \\
\hline & $\begin{array}{l}\text { No. } \\
\text { Tested }\end{array}$ & $\begin{array}{l}\text { No. } \\
\text { +ve }\end{array}$ & $\begin{array}{l}\text { Allele } \\
\text { Type }\end{array}$ & $\begin{array}{l}\text { No. } \\
\text { Tested }\end{array}$ & $\begin{array}{l}\text { No. } \\
\text { +ve }\end{array}$ & $\begin{array}{l}\text { Allele } \\
\text { Type }\end{array}$ & $\begin{array}{l}\text { No. } \\
\text { Tested }\end{array}$ & $\begin{array}{l}\text { No. } \\
\text { +ve }\end{array}$ & $\begin{array}{l}\text { Allele } \\
\text { Type }\end{array}$ & $\begin{array}{l}\text { No. } \\
\text { Tested }\end{array}$ & $\begin{array}{l}\text { No. } \\
\text { +ve }\end{array}$ & $\begin{array}{l}\text { Allele } \\
\text { Type }\end{array}$ & $\begin{array}{l}\text { No. } \\
\text { Tested }\end{array}$ & $\begin{array}{l}\text { No. } \\
\text { +ve }\end{array}$ & Allele Type \\
\hline $\begin{array}{l}\text { Amblyomma } \\
\text { pomposum }\end{array}$ & 2 & 2 & $\begin{array}{l}\text { G2, } \\
\text { G6 }\end{array}$ & 2 & 1 & D20 & 2 & 2 & $\begin{array}{l}\text { R11, } \\
\text { R12 }\end{array}$ & 2 & 1 & 16S-6 & 2 & 2 & $23 \mathrm{~S}-3$ \\
\hline $\begin{array}{c}\text { Amblyomma } \\
\text { variegatum }\end{array}$ & 13 & 7 & G2 & 7 & 1 & D20 & 7 & 7 & $\begin{array}{l}\text { R8, } \\
\text { R11, } \\
\text { R12, } \\
\text { R19 }\end{array}$ & 7 & 2 & $\begin{array}{l}16 \mathrm{~S}-7 \\
16 \mathrm{~S}-8\end{array}$ & 7 & 7 & $23 \mathrm{~S}-3,23 \mathrm{~S}-14$ \\
\hline $\begin{array}{l}\text { Haemaphysalis } \\
\text { aciculifer }\end{array}$ & 9 & 9 & $\begin{array}{l}\text { G5, } \\
\text { G6 }\end{array}$ & 9 & 4 & $\begin{array}{l}\text { D20, } \\
\text { D21, } \\
\text { D22 }\end{array}$ & 9 & 9 & $\begin{array}{l}\text { R2, } \\
\text { R18 }\end{array}$ & 9 & 9 & $\begin{array}{c}16 S-2, \\
16 S-9 \\
16 S-10 \\
16 S-11 \\
16 S-12\end{array}$ & 9 & 9 & $\begin{array}{c}\text { 23S-5, 23S-6, } \\
23 S-15\end{array}$ \\
\hline $\begin{array}{c}\text { Haemaphysalis } \\
\text { elliptica }\end{array}$ & 10 & 4 & $\begin{array}{l}\text { G8, } \\
\text { G11 }\end{array}$ & 4 & 1 & D2 & 4 & 4 & $\begin{array}{l}\text { R7, } \\
\text { R14, } \\
\text { R17 }\end{array}$ & 4 & 4 & $\begin{array}{c}16 S-5 \\
16 S-13 \\
16 S-14\end{array}$ & 4 & 4 & $23 S-7,23 S-12$ \\
\hline $\begin{array}{l}\text { Hyalomma } \\
\text { truncatum }\end{array}$ & 11 & 1 & G2 & 1 & - & - & 1 & 1 & R16 & 1 & - & - & 1 & 1 & $23 S-16$ \\
\hline Ornithodoros faini & 10 & 2 & $\begin{array}{l}\text { G21, } \\
\text { G22 }\end{array}$ & 2 & - & - & 2 & - & - & 2 & - & - & 2 & - & - \\
\hline $\begin{array}{l}\text { Rhipicephalus } \\
\text { appendiculatus }\end{array}$ & 13 & 4 & $\begin{array}{l}\text { G14, } \\
\text { G15 }\end{array}$ & 4 & 4 & $\begin{array}{l}\text { D9, } \\
\text { D18, } \\
\text { D19 }\end{array}$ & 4 & 4 & $\begin{array}{l}\text { R21, } \\
\text { R24 }\end{array}$ & 4 & - & - & 4 & 4 & $\begin{array}{l}23 S-13 \\
23 S-17 \\
23 S-18\end{array}$ \\
\hline $\begin{array}{l}\text { Rhipicephalus } \\
\text { camicasi }\end{array}$ & 1 & 1 & G20 & 1 & 1 & D16 & 1 & 1 & $\mathrm{R} 22$ & 1 & 1 & $16 \mathrm{~S}-15$ & 1 & 1 & $23 \mathrm{~S}-4$ \\
\hline
\end{tabular}


Table 2. Cont.

\begin{tabular}{|c|c|c|c|c|c|c|c|c|c|c|c|c|c|c|c|}
\hline \multirow{3}{*}{ Tick Species } & \multicolumn{15}{|c|}{ CLE Target Gene } \\
\hline & \multicolumn{3}{|c|}{ groEL } & \multicolumn{3}{|c|}{$d n a K$} & \multicolumn{3}{|c|}{ rpoB } & \multicolumn{3}{|c|}{ 16S rRNA } & \multicolumn{3}{|c|}{$23 S$ rRNA } \\
\hline & $\begin{array}{l}\text { No. } \\
\text { Tested }\end{array}$ & $\begin{array}{l}\text { No. } \\
\text { +ve }\end{array}$ & $\begin{array}{l}\text { Allele } \\
\text { Type }\end{array}$ & $\begin{array}{l}\text { No. } \\
\text { Tested }\end{array}$ & $\begin{array}{l}\text { No. } \\
\text { +ve }\end{array}$ & $\begin{array}{l}\text { Allele } \\
\text { Type }\end{array}$ & $\begin{array}{l}\text { No. } \\
\text { Tested }\end{array}$ & $\begin{array}{l}\text { No. } \\
\text { +ve }\end{array}$ & $\begin{array}{l}\text { Allele } \\
\text { Type }\end{array}$ & $\begin{array}{l}\text { No. } \\
\text { Tested }\end{array}$ & $\begin{array}{l}\text { No. } \\
\text { +ve }\end{array}$ & $\begin{array}{l}\text { Allele } \\
\text { Type }\end{array}$ & $\begin{array}{l}\text { No. } \\
\text { Tested }\end{array}$ & $\begin{array}{l}\text { No. } \\
\text { +ve }\end{array}$ & Allele Type \\
\hline $\begin{array}{l}\text { Rhipicephalus } \\
\text { decoloratus }\end{array}$ & 10 & 4 & $\begin{array}{l}\text { G4, } \\
\text { G9 }\end{array}$ & 4 & 4 & $\begin{array}{l}\text { D4, } \\
\text { D10 }\end{array}$ & 4 & 4 & R6 & 4 & - & - & 4 & 4 & 23S-19 \\
\hline $\begin{array}{l}\text { Rhipicephalus } \\
\text { evertsi evertsi }\end{array}$ & 1 & 1 & G18 & 1 & - & - & 1 & 1 & $\mathrm{R} 21$ & 1 & - & - & 1 & 1 & $23 S-20$ \\
\hline $\begin{array}{c}\text { Rhipicephalus } \\
\text { geigyi }\end{array}$ & 5 & 1 & G17 & 1 & 1 & D11 & 1 & 1 & R6 & 1 & - & - & 1 & 1 & $23 \mathrm{~S}-21$ \\
\hline $\begin{array}{l}\text { Rhipicephalus } \\
\text { guilhoni }\end{array}$ & 2 & 2 & $\begin{array}{l}\text { G1, } \\
\text { G8 }\end{array}$ & 2 & 1 & D7 & 2 & 2 & R15 & 2 & - & - & 2 & 2 & $23 \mathrm{~S}-4$ \\
\hline $\begin{array}{l}\text { Rhipicephalus } \\
\text { lunulatus }\end{array}$ & 12 & 6 & G7 & 6 & 3 & $\begin{array}{l}\text { D5, } \\
\text { D6 }\end{array}$ & 6 & 6 & $\mathrm{R} 4$ & 6 & 2 & $\begin{array}{l}16 S-16 \\
16 S-17\end{array}$ & 6 & 6 & $\begin{array}{c}23 \mathrm{~S}-9,23 \mathrm{~S}-22 \\
23 \mathrm{~S}-23\end{array}$ \\
\hline $\begin{array}{l}\text { Rhipicephalus } \\
\text { microplus }\end{array}$ & 10 & 4 & $\begin{array}{l}\text { G9, } \\
\text { G16 }\end{array}$ & 4 & 3 & D8 & 4 & 4 & R10 & 4 & 2 & $16 \mathrm{~S}-3$ & 4 & 4 & $23 \mathrm{~S}-8$ \\
\hline $\begin{array}{l}\text { Rhipicephalus } \\
\text { muhsamae }\end{array}$ & 2 & 2 & G8 & 2 & 1 & D22 & 2 & 2 & R7 & 2 & - & - & 2 & 2 & $23 S-12$ \\
\hline $\begin{array}{l}\text { Rhipicephalus } \\
\text { sanguineus }\end{array}$ & 13 & 7 & $\begin{array}{l}\text { G1, } \\
\text { G19 }\end{array}$ & 7 & 7 & $\begin{array}{l}\text { D2, } \\
\text { D13, } \\
\text { D14, }\end{array}$ & 7 & 7 & $\begin{array}{l}\text { R3, } \\
\text { R20 }\end{array}$ & 7 & 3 & $\begin{array}{l}16 S-18 \\
16 S-19 \\
16 S-20\end{array}$ & 7 & 7 & $23 S-1,23 S-24$ \\
\hline $\begin{array}{l}\text { Rhipicephalus } \\
\text { simus }\end{array}$ & 8 & 8 & G3 & 8 & 8 & D1 & 8 & 8 & $\mathrm{R} 1$ & 8 & 7 & 16S-1 & 8 & 8 & $23 \mathrm{~S}-2$ \\
\hline $\begin{array}{l}\text { Rhipicephalus } \\
\text { sulcatus }\end{array}$ & 6 & 4 & G1 & 4 & 2 & D2 & 4 & 4 & R3 & 4 & 3 & $\begin{array}{l}16 S-21 \\
16 S-22 \\
16 S-23\end{array}$ & 4 & 4 & $23 S-1,23 S-7$ \\
\hline $\begin{array}{c}\text { Rhipicephalus } \\
\text { turanicus }\end{array}$ & 10 & 4 & $\begin{array}{l}\text { G4, } \\
\text { G12 }\end{array}$ & 4 & 4 & $\begin{array}{l}\text { D7, } \\
\text { D12 }\end{array}$ & 4 & 4 & R9 & 4 & 3 & $\begin{array}{l}16 S-24 \\
16 S-25\end{array}$ & 4 & 4 & $23 \mathrm{~S}-4,23 \mathrm{~S}-25$ \\
\hline Rhipicephalus spp. & 10 & 7 & $\begin{array}{l}\text { G10, } \\
\text { G13 }\end{array}$ & 7 & 3 & $\begin{array}{l}\text { D3, } \\
\text { D15 } \\
\text { D17, }\end{array}$ & 7 & 3 & R5 & 7 & 5 & $\begin{array}{c}16 S-4, \\
16 S-26, \\
16 S-27\end{array}$ & 7 & 7 & $\begin{array}{l}23 S-10 \\
23 S-11 \\
23 S-26\end{array}$ \\
\hline
\end{tabular}

No., number; +ve, positive.

Although each tick species had species specific unique alleles of CLEs, some exceptions were observed where the same allele of CLEs was conserved among different tick genera or species. For example, in the $d n a K$ gene, allele D3 was shared by CLE from Am. variegatum, $R$. appendiculatus, R. lunulatus, and unclassified Rhipicephalus spp. and in the groEL gene, G2 was shared by CLE from Am. pomposum, Am. variegatum, and Hy. truncatum (Table 2).

The phylogenetic analysis based on the CLE alleles obtained for each gene were constructed for $16 \mathrm{~S}$ rRNA and groEL genes in Figures 2 and 3, respectively, and dnaK, $23 \mathrm{~S}$ rRNA, and rрoB genes in Supplementary Figures S1-S3, respectively. The results have shown that CLE alleles from Rhipicephalus species generally clustered together while those from Amblyomma species clustered with Haemaphysalis species. Some alleles of CLEs from Hae. elliptica, R. muhsamae clustered together with the pathogenic $C$. burnetii in all five genes. However, one allele of CLEs from O. faini also clustered with C. burnetii in the groEL tree, which was the only gene in which CLE was amplified in the tick species. In the groEL gene tree, allele G1 was shared by R. guilhoni, R. sanguineus, and R. sulcatus, while allele G8 was shared by Hae. elliptica, R. guilhoni, and R. muhsamae. Furthermore, allele G2 was shared by Am. variegatum, Am. pomposum, and Hy. truncatum. Finally, allele G6 was shared by Am. pomposum and Hae. aciculifer. In the $16 \mathrm{~S}$ rRNA gene, there were no CLE alleles that were shared by different tick species. In the rpoB gene, only allele R6 was shared by R. geigyi and $R$. decoloratus. In the dnaK gene, alleles D2, D7, D20, and D22 were shared by different tick species. In the $23 \mathrm{~S}$ rRNA gene, allele 23S-4 was shared by $R$. turanicus, $R$. camicasi, and $R$. guilhoni while allele 23S-12 was shared by Hae. elliptica and R. muhsamae.

\subsection{Comparison of Alleles of CLE and Their Phylogenetic Relationship with the Host Ticks}

The samples that were successfully sequenced for all five loci were concatenated to produce a matrix of all the five genes. The concatenated sequences were used to construct a phylogenetic tree (Figure 4). The CLEs harbored by ticks of the genus Rhipicephalus 
generally clustered according to the species. However, the CLEs from Am. pomposum and Hae. aciculifer clustered together.

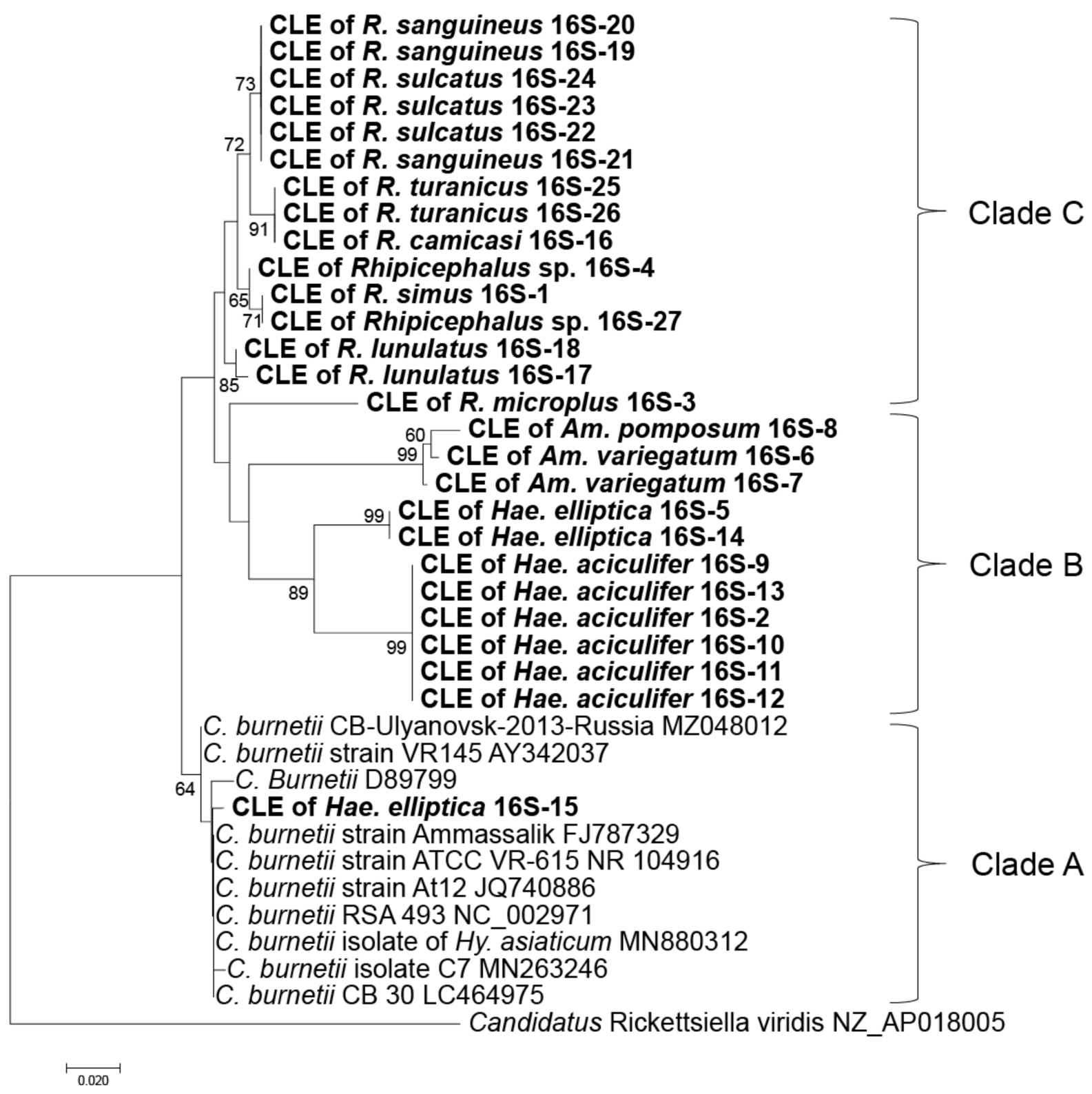

Figure 2. Phylogenetic tree based on the sequences of the CLE 16S rRNA gene. The phylogenetic tree was constructed using MEGA 7 based on the maximum likelihood method, using the Kimura 2-parameter model. All bootstrap values $>60$ from 1000 replications are shown on the interior branch nodes. The sequences obtained in this study are in bold. Allele ID is provided next to the tick species name.

The comparison of the phylogenetic tree based on the concatenated five CLE genes with phylogenetic tree based on the mitochondrial 16S rRNA genes of ticks is shown in Figure 4. The phylogenetic divergence formed from CLEs of ticks was consistent with the phylogenetic divergence of their host ticks. 


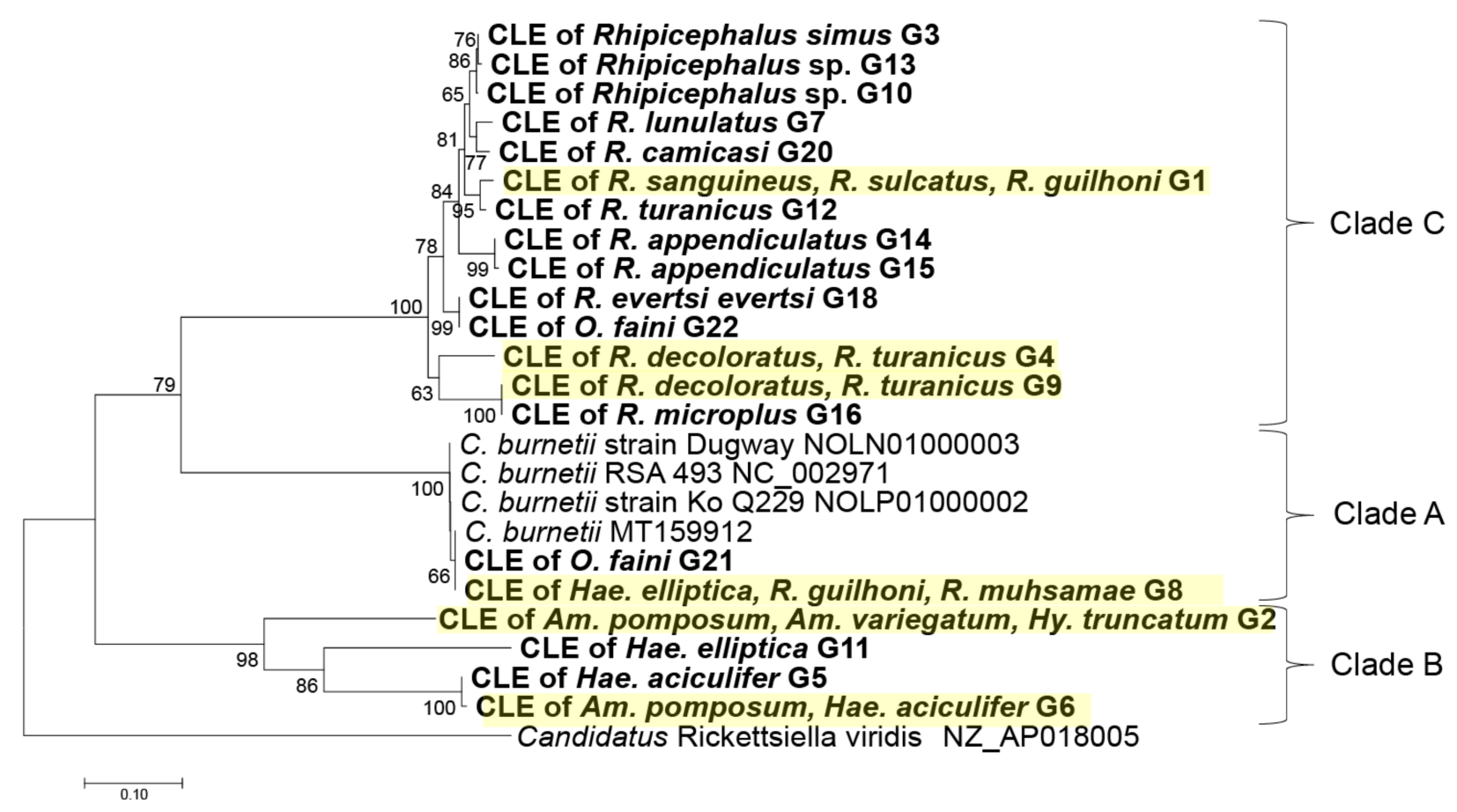

Figure 3. Phylogenetic tree based on the sequences of the CLE groEL gene. The phylogenetic tree was constructed using MEGA7 based on the maximum likelihood method, using the Kimura 2-parameter model. All bootstrap > 60 values from 1000 replications are shown on the interior branch nodes. The sequences obtained in this study are in bold. Alleles that were shared by different tick species have been highlighted in yellow. Allele ID is provided next to the tick species name.

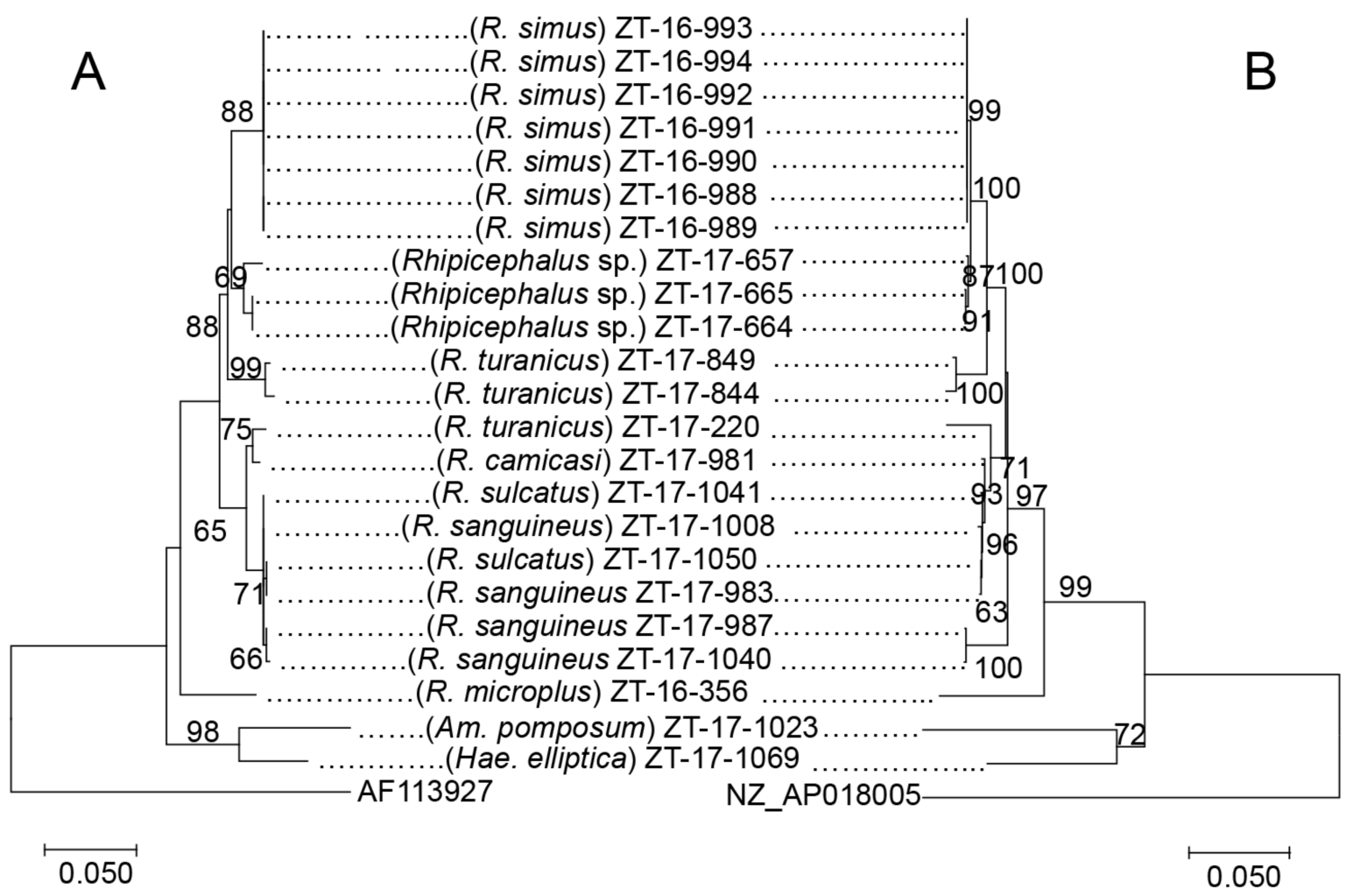

Figure 4. Comparison of phylogenetic trees based on the tick mitochondrial 16S rRNA gene partial sequences (A) and the CLEs concatenated sequences of five ( $(n a K$, groEL, rpoB, $16 \mathrm{~S}$ rRNA, and $23 \mathrm{~S}$ rRNA) genes (B), the trees are rooted with Ixodes pilosus (AF113927) and Candidatus Rickettsiella viridis (NZ_AP018005), respectively. The trees were constructed using MEGA7 based on the maximum likelihood method, using the Kimura 2-parameter model. All bootstrap values $>60$ from 1000 replications are shown on the interior branch nodes. Sample ID is provided next to the tick species name. 


\section{Discussion}

The purpose of this study was to determine the prevalence of CLEs in ticks collected in Zambia and to analyze their relationship with host ticks by genotyping. The CLEs were detected in 80 ticks belonging to 20 species from five genera, including two species of Amblyomma, two species of Haemaphysalis, one species of Hyalomma, one species of Ornithodoros, and 13 species of Rhipicephalus and other unclassified Rhipicephalus spp. On the African continent, CLEs have been reported in a number of tick species, which include Amblyomma cohaerens, Amblyomma gemma, Amblyomma lepidum, Amblyomma personatum, Amblyomma tholloni, Amb. variegatum, Haemaphysalis leachi, Haemaphysalis sp., Hy. truncatum, R. appendiculatus, Rhipicephalus carnivoralis, Rhipicephalus compositus, R. evertsi evertsi, Rhipicephalus maculatus, Rhipicephalus praetextatus, Rhipicephalus pravus, R. sanguineus s.l., and Rhipicephalus sp. [39,40]. This is the first study that investigated CLE in Am. pomposum, Hae. aciculifer, and O. faini.

The groEL PCR assays were used for screening our samples because it is one of the genes that has been used extensively in the studies of CLEs in ticks $[19,20,23]$. The CLE positive detection rates were $98 \%, 93 \%, 61 \%$, and $53 \%$ for $23 \mathrm{~S}$ rRNA, rpoB, dnaK, and $16 \mathrm{~S}$ rRNA genes, respectively, when tested using the 80 samples that were positive on groEL screening PCR. A prior study by Duron et al. [20] showed that in a sub-sample of 85 Coxiella-positive ticks, they were able to obtain multi-locus sequences in $84 \%(n=71)$ of the genes 16S rRNA, 23S rRNA, groEL, and dnaK. Our findings have shown that $23 \mathrm{~S}$ rRNA and rpoB PCR were more sensitive at amplifying CLE-positive samples when compared to dnaK and 16S rRNA PCR in our samples. This suggests that although all the genes targeted for amplification are Coxiella housekeeping genes, the PCR assays for some genes may not be robust enough and lead to false negatives during the amplification of CLEs in this study. Thus, for classification or typing of CLEs, there is a need to develop novel robust MLST primer sets by obtaining the genomic data of CLEs from all the clades of CLEs so that they encompass the genetic diversity of CLEs. It is also possible to use highly comprehensive methods such as bacterial species composition analysis by $16 \mathrm{~S}$ rRNA gene amplicon analysis to detect diverging CLEs than the use of conventional PCR. This approach is supported by the findings of the study where the detection sensitivity of specific bacterial species harbored by ticks was compared between conventional PCR and $16 \mathrm{~S}$ rDNA amplicon analysis and showed that the sensitivity was higher in the latter [3].

The number of alleles of CLEs obtained in this study were 22, 23, 23, 27, and 26 for groEL, rpoB, dnaK, $16 \mathrm{~S}$ rRNA, and $23 \mathrm{~S}$ rRNA genes, respectively. The groEL gene, despite having the highest number of samples successfully sequenced, had the least number of alleles, indicating that this gene is a good marker for screening CLEs and C. burnetii. In contrast, despite having only 42 samples successfully sequenced, $16 \mathrm{~S}$ rDNA had the highest number of alleles at 27 . Though $16 \mathrm{~S}$ rDNA had the least percentage of variable sites at $13.2 \%$ compared to the other four genes examined, the high number of alleles obtained further supports the use of this genetic marker in characterizing CLEs.

Although the tick species showed some species-specific alleles of CLEs, some alleles of CLEs were shared among different tick species. Similarly, the phylogenetic analysis showed that the clades of CLEs were made mainly based on tick genus. Clade A, which includes human pathogenic C. burnetii [20] comprised of $C$. burnetii reference strains and the sequences obtained from Hae. elliptica based on $16 \mathrm{~S}$ rDNA-based tree (Figure 2), while it included the sequences from Hae. elliptica, O. faini, R. guilhoni, and R. muhsamae in a tree based on the groEL gene (Figure 4). Clade B, where CLEs of Haemaphysalis ticks are present along with a presumably pathogenic Coxiella [41], was mainly composed of the sequences obtained from Amblyomma and Haemaphysalis in both 16S rDNA and groE gene-based trees (Figures 2 and 3). Clade C, which includes CLEs from R. turanicus (CRt), a pathogen-derived endosymbiont along with strains causing opportunistic human skin infections [42-46], was comprised of the sequences obtained from Rhipicephalus in both $16 \mathrm{~S}$ rDNA and groEL gene-based trees (Figures 2 and 3). Similar clustering patterns were also observed in the trees based on other genes (Figures S1-S3). The phylogenetic relationship 
of concatenated CLE genes was generally consistent with the phylogenetic tree of the tick's $16 S$ rDNA (Figure 4). The existence of a bias in which sequences of the CLEs possessed by different tick species were conserved within a particular tick species and the strong pattern of co-cladogenesis between ticks and CLEs may be due to vertical transmission of CLEs to the offspring of the ticks [47-49]. In the 16S rRNA gene, we did not observe any alleles that were shared by different tick species. This may be due to the least number of samples being successfully sequenced in this study as well as the low number of variable sites observed in the sequences obtained.

Coxiella burnetii is a Gram-negative intracellular pathogen that has evolved to invade and survive in vertebrate cells [20,50]. Previously, it was suggested that CLE underwent an evolutionary process to $C$. burnetii through genetic mutations and the acquisition of genes that define virulence from other pathogens [23]. However, recent comparative genomic studies supported the opposite view that CLEs have evolved from pathogenic Coxiella independently at multiple time points [51,52]. Nonetheless, it cannot be ruled out that the CLE obtained in this study can have the potential to adapt to vertebrate hosts like C. burnetii. This hypothesis is supported by previous studies, where sequences of CLE obtained from horse blood samples and ticks collected from the horses were identical [50]. Furthermore, an experimental study on the endosymbiont Midichloria mitochondrii in Ixodes ricinus ticks provided evidence of transmission of the endosymbionts to vertebrate hosts during blood feeding [53]. These findings also suggest that the influx of CLE from outside may occur by horizontal transmission through arthropod bites when feeding on host animals. In addition, the detection of symbionts in tick's salivary glands may further support this phenomenon [53]. However, further studies are warranted to validate this hypothesis.

We conducted the phylogenetic analysis of ticks based on their mitochondrial $16 \mathrm{~S}$ rDNA sequences (Figure 1). Similar to a previous report on ticks in Japan [54], we found that the clusters were divided by genus and species, except for members of the $R$. sanguineus s.l.: $R$. camicasi, R. sanguineus, R. sulcatus, R. lunulatus, and R. muhsamae which were mixed in the same clade, indicating that the amplified region of $16 \mathrm{~S}$ rDNA is not suited to discriminate highly related species. Similarly, morphological identification of these ticks remains a big challenge among the tick research community, which is also supported by the report by Dantas-Torres et al. [37] that morphological identification of $R$. turanicus based on only spiracular plates does not correlate with molecular findings. Since most of these ticks resemble each other and due to the lack of type-material and no bona fide morphological description, this has resulted in them being referred to as $R$. sanguineus s.1. [37,55]. This may explain why there is a mix-up among these tick species. In order to understand the exact phylogenetic position of these tick species, detailed phylogenetic analysis using more genes such as complete mitochondrial genome sequencing is required in the future. For instance, the complete mitochondrial genome analysis by Liu et al. [56] provided the evidence that $R$. sanguineus has a number of other closely related species, which cluster together with it hence referred to as $R$. sanguineus complex (sensu lato). Furthermore, complete mitochondrial genome can also help to detect cryptic tick species [57].

The negative results for CLEs in Ar. walkerae, Hy. marginatum rufipes, and Hy. marginatum (Table 1) may be due to presence of other symbionts or divergent CLE species that could not be captured by the PCR primers used in this study. Other tick endosymbionts including Rickettsiella, Midichloria, Lariskella, Francisella, Arsenophonus, Cardinium, Wolbachia, Rickettsia, and Spiroplasma have also been reported in ticks $[8,9,16,17]$. In Hy. marginatum, the endosymbionts FLEs and Midichloria have been reported [9]. Furthermore, we also detected Rickettsia species in the Ar. walkare samples used in this study in our previous study [58]. Similarly, the pathogenic C. burnetii has been reported in Zambia in dogs and rodents [59] but not in ticks. Another study also reported the presence of FLEs in Ornithodoros moubata [60]. Thus, this study does not rule out the presence of other endosymbionts in these ticks.

In this study, we clarified the genetic diversity of ticks and CLEs harbored by ticks collected in Zambia and evaluated the phylogenetic relationship between them. Our 
results showed a strong pattern of co-cladogenesis between ticks and CLEs, confirming the previous results that the vertical route of inheritance is the main one for these nutritional mutualistic symbionts. Thus, further studies are required to investigate the possibility of horizontal transmission of CLEs in particular and the tick endosymbionts in general. This will lead to a better understanding of the physiological characteristics and genetic phylogenetic relationships of ticks and CLEs, which may be applied to the development of tick control methods.

\section{Materials and Methods}

\subsection{Ethical Consideration}

Permission to sample ticks was obtained from the Department of Veterinary Services according to the Animal Health Act No. 27 of 2010 of the Laws of Zambia. Ticks were only sampled from those farmers who agreed to have their cattle and pastures sampled.

\subsection{Tick Collection, Morphological Identification, and DNA Extraction}

A total of 175 individuals ticks were collected from nine sampling sites in Zambia between January 2016 and December 2017 using the flannel flagging method on vegetation and picking up from the body surfaces of livestock (Figure 5). A total of 73 ticks were collected from the environment, while 71, 25, and six ticks were collected from cattle, dogs, and goats, respectively. We included only adult ticks that were apparently not engorged. The ticks were morphologically identified to the species level under a stereomicroscope using established keys [27]. Tick DNA was extracted using TRIzol Reagent (Thermo Fisher Scientific, Waltham, MA, USA) according to manufacturer's recommendations. The concentration of the extracted DNA was measured using Qubit dsDNA BR Assay kit (Thermo Fisher Scientific). The extracted DNA was kept at $-20{ }^{\circ} \mathrm{C}$ until required for use.

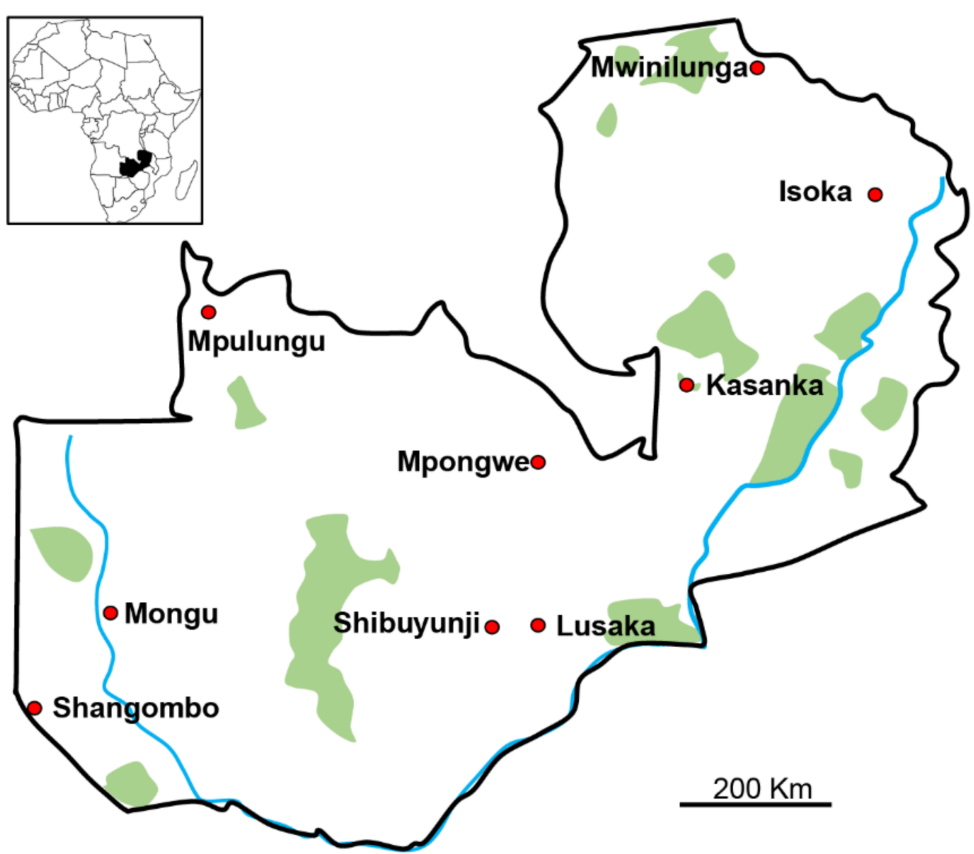

Figure 5. Map of Zambia showing the districts where tick samples were collected.

\subsection{Molecular Tick Identification}

To complement the morphological identification of the ticks and for phylogenetic analysis, PCR amplification targeting tick 16S rDNA was conducted on the utmost three selected samples per tick species according to the previous study [61]. In brief, the PCR was performed using Tks Gflex Polymerase (Takara Bio Inc., Shiga, Japan) in a $10.00 \mu \mathrm{L}$ reaction mixture containing $0.50 \mu \mathrm{L}$ DNA template [1.0-10.0 ng], $5.00 \mu \mathrm{L}$ of $2 \times$ Gflex Buffer, $0.20 \mu \mathrm{L}$ of Tks Gflex Polymerase, $0.20 \mu \mathrm{L}$ of each primer $(10 \mu \mathrm{M})$, and $3.90 \mu \mathrm{L}$ of molecular 
grade water. The PCR condition were initial denaturation at $94{ }^{\circ} \mathrm{C}$ for $1 \mathrm{~min}$, followed by 40 cycles of denaturation at $98^{\circ} \mathrm{C}$ for $10 \mathrm{~s}$, annealing temperature for $15 \mathrm{~s}$, extension at $68^{\circ} \mathrm{C}$ for $1 \mathrm{~min}$, and final extension at $68^{\circ} \mathrm{C}$ for $5 \mathrm{~min}$. The amplicons were electrophoresed in $1.5 \%$ agarose gel stained with Gel-Red (Biotium, Hayward, CA, USA) and visualized under UV light.

\subsection{Detection of CLE and Typing}

All 175 tick samples were tested for the presence of CLEs using a nested PCR assay and sequencing of the groEL gene using Coxiella-specific primers as previously described $[19,20]$. All the primers used in this study, their annealing temperatures, and expected amplicon sizes are indicated in Table 3.

Table 3. List of primers used in this study.

\begin{tabular}{|c|c|c|c|c|c|c|}
\hline Target Gene & Primer Name & Sequence $5^{\prime} \rightarrow 3^{\prime}$ & PCR Type & $\operatorname{Tm}\left({ }^{\circ} \mathrm{C}\right)$ & Fragment Size (bp) & Reference \\
\hline \multirow{2}{*}{ Ticks $16 \mathrm{~S}$ rDNA } & mt-rrs 1 & CTGCTCAATGATTTTTTAAATTGCTGTGG & \multirow{2}{*}{ Single } & \multirow{2}{*}{55} & \multirow{2}{*}{$401-416$} & \multirow{2}{*}{ [61] } \\
\hline & mt-rrs 2 & CCGGTCTGAACTCAGATCAAGTA & & & & \\
\hline \multirow{4}{*}{ Coxiella groEL } & Cox-GrF1 & TTTGAAAAYATGGGCGCKCAAATGGT & \multirow{2}{*}{ 1st PCR } & \multirow{2}{*}{56} & \multirow{2}{*}{655} & \multirow{2}{*}{ [19] } \\
\hline & Cox-GrR2 & CGRTCRCCAAARCCAGGTGC & & & & \\
\hline & Cox-GrF2 & GAAGTGGCTTCGCRTACWTCAGACG & \multirow{2}{*}{ 2nd PCR } & \multirow{2}{*}{56} & \multirow{2}{*}{619} & \multirow{2}{*}{ [20] } \\
\hline & Cox-GrR1 & CCAAARCCAGGTGCTTTYAC & & & & \\
\hline \multirow{8}{*}{ Coxiella dnaK } & Cox-dnaKF1 & CGTCARGCRACGAARGATGCA & \multirow{2}{*}{ 1st PCR } & \multirow{2}{*}{54} & \multirow[b]{2}{*}{777} & \multirow{2}{*}{ [20] } \\
\hline & Cox-dnaKR & CGTCATGAYKCCGCCYAAGG & & & & \\
\hline & Cox-dnaKF3 & GGTACKTTYGATATTTCCATC & \multirow{2}{*}{ Alternative 1st PCR } & \multirow{2}{*}{54} & \multirow{2}{*}{636} & \multirow{2}{*}{ [20] } \\
\hline & Cox-dnaKR & CGTCATGAYKCCGCCYAAGG & & & & \\
\hline & Cox-dnaKF2 & GAAGTGGATGGCGARCAYCAATT & \multirow{2}{*}{ 2nd PCR } & \multirow{2}{*}{54} & \multirow{2}{*}{603} & (2) \\
\hline & Cox-dnaKR & CGTCATGAYKCCGCCYAAGG & & & & {$[20]$} \\
\hline & Cox-dnaKF3 & GGTACKTTYGATATTTCCATC & & & & T200 \\
\hline & Cox-dnaKR3 & CTTGAATAGCYGCACCAATAGC & Aiternative 2nd PCK & 54 & 512 & {$[20]$} \\
\hline & Cox-rpoBF2 & GGGCGNCAYGGWAAYAAAGGSGT & & -6 & 607,610 & Tog \\
\hline Coxiolla $\mathrm{mo} R$ & Cox-rpoBR1 & CACCRAAHCGTTGACCRCCAAATTG & 1st PCR & 56 & $607-610$ & [20] \\
\hline Coxiella rpob & Cox-rpoBF3 & TCGAAGAYATGCCYTATTTAGAAG & & & & S001 \\
\hline & Cox-rpoBR3 & AGCTTTMCCACCSARGGGTTGCTG & 2nd PCR & 56 & $539-542$ & {$[20]$} \\
\hline & Cox-16SF1 & CGTAGGAATCTACCTTRTAGWGG & & & & [10 001 \\
\hline & Cox-16SR2 & GCCTACCCGCTTCTGGTACAATT & 1st PCR & $52-56$ & 1321-1429 & {$[19,20]$} \\
\hline & 16S-07F & AGAGTTTGATYMTGGCTCAG & & $-0-5$ & & [10 010 \\
\hline & Cox-16SR2 & GCCTACCCGCTTCTGGTACAATT & Alternative 1st PCK & $52-56$ & $1434-1542$ & {$[19,20]$} \\
\hline & Cox-16SF1 & CGTAGGAATCTACCTTRTAGWGG & 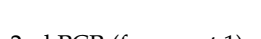 & & & \\
\hline & Cox-16SR1 & ACTYYCCAACAGCTAGTTCTCA & 2nd Ре (Iragment 1) & $52-56$ & $719-826$ & {$[20]$} \\
\hline Coxiella $16 \mathrm{~S}$ rDNA & 16S-07F & AGAGTTTGATYMTGGCTCAG & Alternative 2nd PCR & 50256 & - & (201 \\
\hline & Cox-16SR1 & ACTYYCCAACAGCTAGTTCTCA & (fragment 1) & $32-36$ & $002-909$ & {$[\angle \mathrm{OU}]$} \\
\hline & Cox-16SF2 & TGAGAACTAGCTGTTGGRRAGT & 2nd PCP (fmomt?) & $50-56$ & 601607 & [001 \\
\hline & Cox-16SR2 & GCCTACCCGCTTCTGGTACAATT & Znd PCK (Iragment 2) & $52-56$ & $624-627$ & {$[20]$} \\
\hline & Cox16S_seq1 & TCTACGCATTTCACCGCTAC & & & & \\
\hline & Cox16S_seq2 & AGTCGGATGTGAAAGCCCTA & 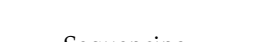 & & & \\
\hline & Cox16S_seq3 & CCTGTCACTCGGTTCCCAAA & Sequencing & & & This study \\
\hline & Cox16S_seq4 & CTGACACTGAGGCCGCGAAAGC & & & & \\
\hline & Cox-23SF1 & GCCTGCGAWAAGCTTCGGGGAG & & & & 5001 \\
\hline & Cox-23SR2 & СТССТАКССАСАSCTCATCCСC & Ist PCR & 56 & $694-1188$ & {$[20]$} \\
\hline & Cox-23SF2 & GATCCGGAGATWTCYGAATGGGG & $10 \mathrm{DCD}-\mathrm{a}$ & 56 & & 5000 \\
\hline Coxiella $23 \mathrm{~S}$ rDNA & Cox-23SR1 & TCGYTCGGTTTCGGGTCKACTC & 2nd PCR run & 56 & $583-86 \%$ & {$[20]$} \\
\hline & Cox-23SF1 & GCCTGCGAWAAGCTTCGGGGAG & & $-G$ & & โר: \\
\hline & Cox-23SR2 & СТССТАКССАСАSСТСАТСССС & Alternative 2nd PCR & 56 & $601-884$ & [20] \\
\hline
\end{tabular}


For the 1st groEL PCR, amplification was carried out in a total of $25.00 \mu \mathrm{L}$ reaction mixture containing $1.00 \mu \mathrm{L}$ of tick DNA template [2.0-20 ng], $12.50 \mu \mathrm{L}$ of $2 \times$ Gflex Buffer, $0.50 \mu \mathrm{L}$ of Tks Gflex Polymerase, $0.50 \mu \mathrm{L}$ of each primer $(10 \mu \mathrm{M})$, and $10.00 \mu \mathrm{L}$ of distilled water. The reaction conditions as described above except that the annealing temperature was adjusted to $56{ }^{\circ} \mathrm{C}$. The 2 nd groEL PCR was performed in a $10.00 \mu \mathrm{L}$ reaction mixture containing $0.50 \mu \mathrm{L}$ of 1 st PCR product as DNA template, $5.00 \mu \mathrm{L}$ of $2 \times$ Gflex Buffer, $0.20 \mu \mathrm{L}$ of Tks Gflex Polymerase, $0.20 \mu \mathrm{L}$ of each primer $(10 \mu \mathrm{M})$, and $3.90 \mu \mathrm{L}$ of molecular grade water. The reaction conditions were the same as that of the 1st PCR. The amplicons were electrophoresed in 1.5\% agarose gel stained with Gel-Red and visualized under UV light.

The samples that were positive for CLEs were further subjected to MLST analysis using nested PCR assays targeting four other Coxiella genes: dnaK, rpoB, 16S rRNA, and 23S rRNA genes as described previously [20]. The PCRs were performed using Tks Gflex Polymerase. The reaction conditions were set as previously described with adjustments in annealing temperatures only. When the initial 1st or 2nd PCR failed, we did an alternative PCR to ensure that we successfully amplify and sequence as many samples as possible. For $16 \mathrm{~S}$ rDNA of CLEs we amplified the $1421 \mathrm{bp}$ fragment in two fragments of $939 \mathrm{bp}$ and $627 \mathrm{bp}$ for fragment 1 and fragment 2, respectively.

\subsection{Sequencing}

The PCR amplicons with single band were purified using ExoSAP-IT (Thermo Fisher Scientific, Santa Clara, CA, USA). When the amplicons in which multiple bands were identified, the band containing the target DNA was cut from the gel and purified using Nucleospin ${ }^{\circledR}$ Gel \& PCR clean-up (Macherey-Nagel., Neumann-Neander, Düren, Germany).

The amplicons of tick 16S rDNA PCR and 2nd PCR for each gene of CLE were sequenced in both directions using forward and reverse primers. The sequencing primers of CLE 16S rDNA were designed in this study. Sequencing reactions were performed in a $10.00 \mu \mathrm{L}$ reaction mixture containing $1.00 \mu \mathrm{L}$ of purified PCR product, $1.75 \mu \mathrm{L}$ of $5 \times$ Sequencing Buffer (Applied Biosystems, Foster City, CA, USA), $0.50 \mu \mathrm{L}$ of BigDye Terminator version 3.1 Cycle Sequencing Kit (Applied Biosystems), $0.32 \mu \mathrm{L}$ of primer $(10 \mu \mathrm{M})$, and $6.43 \mu \mathrm{L}$ of distilled water. The sequencing products were purified using Agencourt CleanSeq (Beckman Coulter Inc., Brea, CA, USA) and sequenced on 3130xL Genetic Analyzer (Applied Biosystems).

\subsection{Data Analysis}

Sequences were analyzed using GENETYX version 9.1 (GENETYX Corporation, Tokyo, Japan), they were trimmed on both the 5' and 3' ends to remove the primer annealing sites as described previously [62]. The number and percentage of variable sites were calculated using DnaSP v6 [63]. The consensus CLE and tick 16S rDNA sequences obtained in this study were submitted to the DNA Data Bank of Japan (DDBJ) under accession numbers (groEL gene: LC634776-LC634852; dnaK gene: LC634853-LC634906; rpoB gene: LC634907LC634982; 16S rDNA: LC635154-LC635193; and 23S rDNA: LC635194-LC635266, tick mitochondrial 16S rDNA: LC634544-LC634602). Then, phylogenetic trees were constructed in MEGA 7 [64] using the maximum likelihood method with the Kimura 2-parameter model. To test for confidence, the bootstrap values were calculated using 1000 replications.

\section{Conclusions}

We confirmed that 80 ticks of 20 species in five genera harbored CLEs, but ticks belonging to three species in two genera were all negative for CLE. Each tick species showed predisposition to specific alleles of CLE with some exceptions. The phylogenetic relationship between tick species and their CLE was generally consistent. From this study, it was confirmed that many tick species in Zambia possess CLE. On the other hand, the existence of tick species that do not possess CLE was also confirmed, suggesting the existence of other symbiotic bacteria which may perform similar functions. Comparison of the phylogenetic relationship between ticks and CLE suggested that most of the CLE 
were inherited by vertical transmission, but there was also a possibility that CLE were introduced from outside by horizontal transmission. In future studies, clarification of the microbiological characteristics of CLE is expected to lead to a better understanding of the physiological characteristics of ticks.

Supplementary Materials: The following are available online at https: / www.mdpi.com/article/ 10.3390 / pathogens10060779/s1, Figure S1: Phylogenetic tree based on the sequences of $d n a K$ gene; Figure S2: Phylogenetic tree based on the sequences of 23S rRNA gene; Figure S3: Phylogenetic tree based on the sequences of $r p o B$ gene.

Author Contributions: Conceptualization, E.C. and R.N.; methodology, T.K. and E.C.; software, T.K. and E.C.; validation, E.C. and R.N.; formal analysis, T.K. and E.C. and R.N.; investigation, T.K. and E.C.; resources, Y.Q., M.S., M.K., B.M.H., Y.E., N.S., A.M.-K. and E.S.; data curation, T.K. and E.C.; writing-original draft preparation, T.K. and E.C.; writing-review and editing, R.N.; visualization, T.K. and E.C.; supervision, R.N., K.K. and N.N.; project administration, R.N.; funding acquisition, R.N., A.T. and H.S.; All authors have read and agreed to the published version of the manuscript.

Funding: This research was funded by JSPS KAKENHI (16H06431, 19H03118, 19F19097, 20K21358, and 20KK0151), the Japan Program for Infectious Diseases Research and Infrastructure (20wm02250 16j0001) from the Japan Agency for Medical Research and Development (AMED), and the Science and Technology Research Partnership for Sustainable Development (SATREPS) (JP20jm0110019) through the Japan International Cooperation Agency (JICA) and AMED.

Institutional Review Board Statement: Permission to sample ticks was obtained from the Department of Veterinary Services according to the Animal Health Act No. 27 of 2010 of the Laws of Zambia.

Informed Consent Statement: Informed consent was sought from the owners of the pastures and animals. Ticks were only sampled from those farmers who agreed to have their cattle and pastures sampled.

Data Availability Statement: The CLE and tick sequences obtained in this study were submitted to the DNA Data Bank of Japan (DDBJ) under accession numbers (groEL gene: LC634776-LC634852; dnaK gene: LC634853-LC634906; rpoB gene: LC634907-LC634982; 16S rDNA: LC635154-LC635193; and 23S rDNA: LC635194-LC635266, tick mitochondrial 16S rDNA: LC634544-LC634602).

Conflicts of Interest: The authors declare no conflict of interest.

\section{References}

1. Nicholson, W.L.; Sonenshine, D.E.; Noden, B.H.; Brown, R.N. Ticks (Ixodida). Med. Vet. Entomol. 2019, 603-672. [CrossRef]

2. Nakao, R.; Abe, T.; Nijhof, A.M.; Yamamoto, S.; Jongejan, F.; Ikemura, T.; Sugimoto, C. A novel approach, based on BLSOMs (Batch Learning Self-Organizing Maps), to the microbiome analysis of ticks. ISME J. 2013, 7, 1003-1015. [CrossRef] [PubMed]

3. Qiu, Y.; Nakao, R.; Ohnuma, A.; Kawamori, F.; Sugimoto, C. Microbial population analysis of the salivary glands of ticks; a possible strategy for the surveillance of bacterial pathogens. PLoS ONE 2014, 9, e0103961. [CrossRef] [PubMed]

4. Palomar, A.M.; Portillo, A.; Santibáñez, P.; Mazuelas, D.; Arizaga, J.; Crespo, A.; Gutiérrez, Ó.; Cuadrado, J.F.; Oteo, J.A. CrimeanCongo hemorrhagic fever virus in ticks from migratory birds, Morocco. Emerg. Infect. Dis. 2013, 19, 260-263. [CrossRef] [PubMed]

5. Arraga-Alvarado, C.M.; Qurollo, B.A.; Parra, O.C.; Berrueta, M.A.; Hegarty, B.C.; Breitschwerdt, E.B. Case report: Molecular evidence of Anaplasma platys infection in two women from Venezuela. Am. J. Trop. Med. Hyg. 2014, 91, 1161-1165. [CrossRef]

6. Maggi, R.G.; Mascarelli, P.E.; Havenga, L.N.; Naidoo, V.; Breitschwerdt, E.B. Coinfection with Anaplasma platys, Bartonella henselae and Candidatus Mycoplasma haematoparvum in a veterinarian. Parasite Vectors 2013, 6, 103. [CrossRef]

7. Erik, M.F.; Vizzoni, V.F.; Balsemão-Pires, E.; Moerbeck, L.; Gazeta, G.S.; Piesman, J.; Voloch, C.M.; Soares, C.A.G. Coxiella symbionts are widespread into hard ticks. Parasitol. Res. 2016, 115, 4691-4699. [CrossRef]

8. Bonnet, S.I.; Binetruy, F.; Hernández-Jarguín, A.M.; Duron, O. The tick microbiome: Why non-pathogenic microorganisms matter in tick biology and pathogen transmission. Front. Cell. Infect. Microbiol. 2017, 7. [CrossRef]

9. Duron, O.; Binetruy, F.; Noël, V.; Cremaschi, J.; McCoy, K.D.; Arnathau, C.; Plantard, O.; Goolsby, J.; Pérez de León, A.A.; Heylen, D.J.A.; et al. Evolutionary changes in symbiont community structure in ticks. Mol. Ecol. 2017, 26, 2905-2921. [CrossRef]

10. Rio, R.; Attardo, G.M.; Weiss, B.L. Grandeur Alliances: Symbiont Metabolic Integration and Obligate Arthropod Hematophagy. Trends Parasitol. 2016, 32, 739-749. [CrossRef]

11. Hosokawa, T.; Koga, R.; Kikuchi, Y.; Meng, X.Y.; Fukatsu, T. Wolbachia as a bacteriocyte-associated nutritional mutualist. Proc. Natl. Acad. Sci. USA 2010, 107, 769-774. [CrossRef]

12. Cirimotich, C.; Dong, Y.; Clayton, A.; Sandiford, S.; Souza-Neto, J.; Mulenga, M.; Dimopoulos, G. Natural Microbe-Mediated Refractoriness to Plasmodium Infection in Anopheles gambiae. Science 2011, 332, 855-858. [CrossRef] 
13. Moreira, L.A.; Iturbe-Ormaetxe, I.; Jeffery, J.A.; Lu, G.; Pyke, A.T.; Hedges, L.M.; Rocha, B.C.; Hall-Mendelin, S.; Day, A.; Riegler, M.; et al. A Wolbachia Symbiont in Aedes aegypti Limits Infection with Dengue, Chikungunya, and Plasmodium. Cell 2009, 139, 1268-1278. [CrossRef]

14. Klyachko, O.; Stein, B.D.; Grindle, N.; Clay, K.; Fuqua, C. Localization and visualization of a Coxiella-type symbiont within the lone star tick, Amblyomma americanum. Appl. Environ. Microbiol. 2007, 73, 6584-6594. [CrossRef]

15. Machado-Ferreira, E.; Dietrich, G.; Hojgaard, A.; Levin, M.; Piesman, J.; Zeidner, N.S.; Soares, C.A.G. Coxiella Symbionts in the Cayenne Tick Amblyomma cajennense. Microb. Ecol. 2011, 62, 134-142. [CrossRef]

16. Díaz-S 'anchez, S.; Estrada-Pena, A.; Cabezas-Cruz, A.; de la Fuente, J. Evolutionary insights into the tick hologenome. Trends Parasitol. 2019, 35, 725-737. [CrossRef]

17. Narasimhan, S.; Fikrig, E. Tick microbiome: The force within. Trends Parasitol. 2015, 31, 315-323. [CrossRef]

18. Noda, H.; Munderloh, U.G.; Kurtti, T.J. Endosymbionts of ticks and their relationship to Wolbachia spp. and tick-borne pathogens of humans and animals. Appl. Environ. Microbiol. 1997, 63, 3926-3932. [CrossRef]

19. Duron, O.; Jourdain, E.; McCoy, K.D. Diversity and global distribution of the Coxiella intracellular bacterium in seabird ticks. Ticks Tick Borne Dis. 2014, 5, 557-563. [CrossRef]

20. Duron, O.; Noël, V.; McCoy, K.D.; Bonazzi, M.; Sidi-Boumedine, K.; Morel, O.; Vavre, F.; Zenner, L.; Jourdain, E.; Durand, P.; et al. The Recent Evolution of a Maternally-Inherited Endosymbiont of Ticks Led to the Emergence of the Q Fever Pathogen, Coxiella burnetii. PLoS Pathog. 2015, 11, e1004892. [CrossRef]

21. Smith, T.A.; Driscoll, T.; Gillespie, J.J.; Raghavan, R. A Coxiella-like endosymbiont is a potential vitamin source for the lone star tick. Genome Biol. Evol. 2015, 7, 831-838. [CrossRef] [PubMed]

22. Almeida, A.P.; Marcili, A.; Leite, R.C.; Nieri-Bastos, F.A.; Domingues, L.N.; Martins, J.R.; Labruna, M.B. Coxiella symbiont in the tick Ornithodoros rostratus (Acari: Argasidae). Ticks Tick Borne Dis. 2012, 3, 203-206. [CrossRef] [PubMed]

23. Duron, O.; Schneppat, U.E.; Berthomieu, A.; Goodman, S.M.; Droz, B.; Paupy, C.; Obame Nkoghe, J.; Rahola, N.; Tortosa, P. Origin, acquisition and diversification of heritable bacterial endosymbionts in louse flies and bat flies. Mol. Ecol. 2014, 23, $2105-2117$. [CrossRef] [PubMed]

24. Lalzar, I.; Harrus, S.; Mumcuoglu, K.Y.; Gottlieb, Y. Composition and seasonal variation of Rhipicephalus turanicus and Rhipicephalus sanguineus bacterial communities. Appl. Environ. Microbiol. 2012, 78, 4110-4116. [CrossRef]

25. Jasinskas, A.; Zhong, J.; Barbour, A.G. Highly prevalent Coxiella sp. bacterium in the tick vector Amblyomma americanum. Appl. Environ. Microbiol. 2007, 73, 334-336. [CrossRef]

26. Clay, K.; Klyachko, O.; Grindle, N.; Civitello, D.; Oleske, D.; Fuqua, C. Microbial communities and interactions in the lone star tick, Amblyomma americanum. Mol. Ecol. 2008, 17, 4371-4381. [CrossRef]

27. Walker, A., R.; Bouattor, J.L.; Camicas, A.; Estrada-Pena, I.G.; Horak, A.A.; Latiff, R.G.; Pegram, P.M. Ticks of Domestic Animals in Africa: A Guide to Identification of Species; Bioscience Reports: Edinburgh Scotland, UK, 2003; pp. 1-221. ISBN 0-9545173-0-X.

28. Qiu, Y.; Hokkaido University, Sapporo, Hokkaido, Japan. Personal communication, 2018.

29. Simuunza, M.; Weir, W.; Courcier, E.; Tait, A.; Shiels, B. Epidemiological analysis of tick-borne diseases in Zambia. Vet. Parasitol. 2011, 175, 331-342. [CrossRef]

30. Ahmadu, B.; Lovelace, C.E.; Samui, K.L.; Mahan, S. Some observations on the seroprevalence of heartwater and tick infestation in Zambian goats. Onderstepoort J. Vet. Res. 2004, 71, 161-164. [CrossRef]

31. Makala, L.H.; Mangani, P.; Fujisaki, K.; Nagasawa, H. The current status of major tick borne diseases in Zambia. Vet. Res. 2003, 34, 27-45. [CrossRef]

32. De Castro, J.J.; James, A.D.; Minjauw, B.; Di Giulio, G.U.; Permin, A.; Pegram, R.G.; Chizyuka, H.G.B.; Sinyangwe, P. Long-term studies on the economic impact of ticks on Sanga cattle in Zambia. Exp. Appl. Acarol. 1997, 21, 3-19. [CrossRef]

33. Qiu, Y.; Nakao, R.; Hang'ombe, B.M.; Sato, K.; Kajihara, M.; Kanchela, S.; Changula, K.; Eto, Y.; Ndebe, J.; Sasaki, M.; et al. Human Borreliosis Caused by a New World Relapsing Fever Borrelia-like Organism in the Old World. Clin. Infect. Dis. 2019, 69, 107-112. [CrossRef]

34. Qiu, Y.; Kaneko, C.; Kajihara, M.; Saasa, N.; Simulundu, E.; Muleya, W.; Thu, M.J.; Hang'ombe, M.B.; Katakura, K.; Takada, A.; et al. Tick-borne haemoparasites and Anaplasmataceae in domestic dogs in Zambia. Ticks Tick Borne Dis. 2018, 9, 988-995. [CrossRef]

35. Vlahakis, P.A.; Chitanga, S.; Simuunza, M.C.; Simulundu, E.; Qiu, Y.; Changula, K.; Chambaro, H.M.; Kajihara, M.; Nakao, R.; Takada, A.; et al. Molecular detection and characterization of zoonotic Anaplasma species in domestic dogs in Lusaka, Zambia. Ticks Tick Borne Dis. 2018, 9, 39-43. [CrossRef]

36. Beati, L.; Patel, J.; Lucas-Williams, H.; Adakal, H.; Kanduma, E.G.; Tembo Mwase, E.; Krecek, R.; Mertins, J.W.; Alfred, J.T.; Kelly, S.; et al. Phylogeography and demographic history of Amblyomma variegatum (Fabricius) (Acari: Ixodidae), the tropical bont tick. Vector Borne Zoonotic Dis. 2012, 12, 514-525. [CrossRef]

37. Dantas-Torres, F.; Maia, C.; Latrofa, M.S.; Annoscia, G.; Cardoso, L.; Otranto, D. Genetic characterization of Rhipicephalus sanguineus (sensu lato) ticks from dogs in Portugal. Parasite Vectors 2017, 10, 133. [CrossRef]

38. Pegram, R.G.; Clifford, C.M.; Walker, J.B.; Keirans, J.E. Clarification of the Rhipicephalus sanguineus group (Acari, Ixodoidea, Ixodidae). I. R. sulcatus Neumann, 1908 and R. turanicus Pomerantsev, 1936. Syst. Parasitol. 1987, 10, 3-26. [CrossRef]

39. Olivieri, E.; Kariuki, E.; Floriano, A.M.; Castelli, M.; Tafesse, Y.M.; Magoga, G.; Kumsa, B.; Montagna, M.; Sassera, D. Multicountry investigation of the diversity and associated microorganisms isolated from tick species from domestic animals, wildlife and vegetation in selected African countries. Exp. Appl. Acarol. 2021, 83, 427-448. [CrossRef] 
40. Oundo, J.W.; Villinger, J.; Jeneby, M.; Ong'amo, G.; Otiende, M.Y.; Makhulu, E.E.; Musa, A.A.; Ouso, D.O.; Wambua, L. Pathogens, endosymbionts, and blood-meal sources of host-seeking ticks in the fast-changing Maasai Mara wildlife ecosystem. PLoS ONE 2020, 5, e0228366. [CrossRef]

41. Seo, M.G.X.; Lee, S.H.; Ouh, I.O.; Lee, G.H.; Goo, Y.K.; Kim, S.; Kwon, O.D.; Kwak, D. Molecular detection and genotyping of Coxiella-like endosymbionts in ticks that infest horses in South Korea. PLoS ONE 2016, 11, e0165784. [CrossRef]

42. Gottlieb, Y.; Lalzar, I.; Klasson, L. Distinctive genome reduction rates revealed by genomic analyses of two Coxiella-like endosymbionts in ticks. Genome Biol. Evol. 2015, 7, 1779-1796. [CrossRef]

43. Angelakis, E.; Thiberville, S.D.; Million, M.; Raoult, D. Sternoclavicular joint infection caused by Coxiella burnetii: A case report. J. Med. Case Rep. 2016, 10, 139. [CrossRef]

44. Guimard, T.; Amrane, S.; Prudent, E.; El Karkouri, K.; Raoult, D.; Angelakis, E. Case Report: Scalp Eschar and Neck Lymphadenopathy Associated with Bacteremia due to Coxiella-Like Bacteria. Am. J. Trop. Med. Hyg. 2017, 97, 1319-1322. [CrossRef]

45. Tsementzi, D.; Gordillo, C.J.; Mahagna, M.; Gottlieb, Y.; Konstantinidis, K.T. Comparison of closely related, uncultivated Coxiella tick endosymbiont population genomes reveals clues about the mechanisms of symbiosis. Environ. Microbiol. 2018, 20, 1751-1764. [CrossRef]

46. Ben-Yosef, M.; Rot, A.; Mahagna, M.; Kapri, E.; Behar, A.; Gottlieb, Y. Coxiella-like endosymbiont of Rhipicephalus sanguineus is required for physiological processes during ontogeny. Front. Microbiol. 2020, 11, 493. [CrossRef]

47. Wernegreen, J.J. Endosymbiosis. Curr. Biol. 2012, 22, 555-561. [CrossRef]

48. Bennett, G.M.; Moran, N.A. Heritable symbiosis: The advantages and perils of an evolutionary rabbit hole. Proc. Natl. Acad. Sci. USA 2015, 112, 10169-10176. [CrossRef]

49. Van Schaik, E.; Chen, C.; Mertens, K.; Weber, M.M.; Samuel, J.E. Molecular pathogenesis of the obligate intracellular bacterium Coxiella burnetii. Nat. Rev. Microbiol. 2013, 11, 561-573. [CrossRef]

50. Seo, M.G.; Lee, S.H.; VanBik, D.; Ouh, I.O.; Yun, S.H.; Choi, E.; Park, Y.S.; Lee, S.E.; Kim, J.W.; Cho, G.J.; et al. Detection and genotyping of Coxiella burnetii and Coxiella-like bacteria in horses in South Korea. PLoS ONE 2016, 11, e0156710. [CrossRef]

51. Nardi, T.; Olivieri, E.; Kariuki, E.; Sassera, D.; Castelli, M. Sequence of a Coxiella endosymbiont of the tick Amblyomma nuttalli suggests a pattern of convergent genome reduction in the Coxiella genus. Genome Biol. Evol. 2021, 13, 1. [CrossRef]

52. Brenner, A.E.; Muñoz-Leal, S.; Sachan, M.; Labruna, M.B.; Raghavan, R. Coxiella burnetii and related tick endosymbionts evolved from pathogenic ancestors. Genome Biol. Evol. 2021. [CrossRef]

53. Cafiso, A.; Sassera, D.; Romeo, C.; Serra, V.; Hervet, C.; Bandi, C.; Plantard, O.; Bazzocchi, C. Midichloria mitochondrii, endosymbiont of Ixodes ricinus: Evidence for the transmission to the vertebrate host during the tick blood meal. Ticks Tick Borne Dis. 2018 [CrossRef] [PubMed]

54. Takano, A.; Toyomane, K.; Konnai, S.; Ohashi, K.; Nakao, M.; Ito, T.; Andoh, M.; Maeda, K.; Watarai, M.; Sato, K.; et al. Tick Surveillance for Relapsing Fever Spirochete Borrelia miyamotoi in Hokkaido, Japan. PLoS ONE 2014, 9, e104532. [CrossRef] [PubMed]

55. Nava, S.; Estrada-Peña, A.; Petney, T.; Beati, L.; Labruna, M.B.; Szabó, M.P.; José, M.; Venzal, J.M.; Mastropaolo, M.; Mangold, A.J.; et al. The taxonomic status of Rhipicephalus sanguineus (Latreille, 1806). Vet. Parasitol. 2015, 208, 2-8. [CrossRef] [PubMed]

56. Liu, G.H.; Chen, F.; Chen, Y.Z.; Song, H.Q.; Lin, R.Q.; Zhou, D.H.; Zhu, X.Q. Complete mitochondrial genome sequence data provides genetic evidence that the brown dog tick Rhipicephalus sanguineus (Acari: Ixodidae) represents a species complex. Int. J. Biol. Sci. 2013, 9, 361-369. [CrossRef]

57. McCann, K.M.; Grant, W.N.; Spratt, D.M.; Shannon, M.; Hedtke, S.M. Cryptic species diversity in ticks that transmit disease in Australia. Int. J. Parasitol. Parasite Wildl. 2019, 10, 125-131. [CrossRef]

58. Qiu, Y.; Simuunza, M.; Kajihara, M.; Chambaro, M.; Harima, H.; Eto, Y.; Simulundu, E.; Squarre, D.; Torii, S.; Takada, A.; et al. Screening of tick-borne pathogens in argasid ticks in Zambia: Expansion of the geographic distribution of Rickettsia lusitaniae and Rickettsia hoogstraalii and detection of putative novel Anaplasma species. Ticks Tick Borne Dis. 2021, 12. [CrossRef]

59. Chitanga, S.; Simulundu, E.; Simuunza, M.C.; Changula, K.; Qiu, Y.; Kajihara, M.; Nakao, R.; Syakalima, M.; Takada, A.; Mweene, A.S.; et al. First molecular detection and genetic characterization of Coxiella burnetii in Zambian dogs and rodents. Parasite Vectors 2018, 11, 40. [CrossRef]

60. Duron, O.; Morel, O.; Nöel, V.; Buysse, M.; Binetruy, F.; Lancelot, R.; Loire, E.; M.'enard, C.; Bouchez, O.; Vavre, F.; et al. Tick-bacteria mutualism depends on B vitamin synthesis pathways. Curr. Biol. 2018, 28, 1896-1902. [CrossRef]

61. Ushijima, Y.; Oliver, J.H.; Keirans, J.E.; Tsurumi, M.; Kawabata, H.; Watanabe, H.; Fukunaga, M. Mitochodrial Sequence Variation in Carios capensis (Neumann), a Parasite of Seabirds, Collected on Torishima Island in Japan. J. Parasitol. 2003, 89, 196-198. [CrossRef]

62. Nakao, R.; Qiu, Y.; Igarashi, M.; Magona, J.W.; Zhoua, L.; Ito, K.; Sugimoto, C. High prevalence of spotted fever group rick-ettsiae in Amblyomma variegatum from Uganda and their identification using sizes of intergenic spacers. Ticks Tick Borne Dis. 2013, 4, 506-512. [CrossRef]

63. Rozas, J.; Ferrer-Mata, A.; Sánchez-DelBarrio, J.C.; Guirao-Rico, S.; Librado, P.; Ramos-Onsins, S.; Sanchez-Gracia, A. DnaSP 6: DNA Sequence Polymorphism Analysis of Large Data Sets. Mol. Boil. Evol. 2017, 34, 3299-3302. [CrossRef]

64. Kumar, S.; Stecher, G.; Tamura, K. MEGA 7: Molecular evolutionary genetics analysis across computing platforms. Mol. Biol Evol. 2016, 33, 1870-1874. [CrossRef] 